\title{
In vitro AND in situ ACTIVATION OF THE COMPLEMENT SYSTEM BY THE FUNGUS Lacazia loboi
}

\author{
Fátima Regina VILANI-MORENO(1), Érika MOZER(2), Ana Márcia Guedes de SENE(2), Margarete de Oliveira FERASÇOLI(2), Tânia Cristina PEREIRA(2), \\ Márcia Garcia MIRAS(2), Gláucia Heloísa de Paula SOUZA(3) \& Andréa de Faria Fernandes BELONE(3)
}

\begin{abstract}
SUMMARY
Since there are no studies evaluating the participation of the complement system (CS) in Jorge Lobo's disease and its activity on the fungus Lacazia loboi, we carried out the present investigation. Fungal cells with a viability index of $48 \%$ were obtained from the footpads of BALB/c mice and incubated with a pool of inactivated serum from patients with the mycosis or with sterile saline for $30 \mathrm{~min}$ at $37^{\circ} \mathrm{C}$. Next, the tubes were incubated for $2 \mathrm{~h}$ with a pool of noninactivated $\mathrm{AB}^{+}$serum, inactivated serum, serum diluted in EGTA- $\mathrm{MgCl}_{2}$, and serum diluted in EDTA. The viability of $L$. loboi was evaluated and the fungal suspension was cytocentrifuged. The slides were submitted to immunofluorescence staining using human anti-C3 antibody. The results revealed that $98 \%$ of the fungi activated the CS by the alternative pathway and no significant difference in $L$. loboi viability was observed after CS activation. In parallel, frozen histological sections from 11 patients were analyzed regarding the presence of $\mathrm{C} 3$ and IgG by immunofluorescence staining. C3 and IgG deposits were observed in the fungal wall of $100 \%$ and $91 \%$ of the lesions evaluated, respectively. The results suggest that the CS and immunoglobulins may contribute to the defense mechanisms of the host against L. loboi.
\end{abstract}

KEYWORDS: Complement system; Lacazia loboi; Jorge Lobo's disease; Immunofluorescence; Skin lesions.

\section{INTRODUCTION}

Lacazia loboi is the etiological agent of Jorge Lobo's disease ${ }^{25}$, a chronic cutaneous-subcutaneous mycosis first described by Jorge de Oliveira Lobo in 1931 in a patient from the Amazon region ${ }^{13}$. This mycosis occurs predominantly in Brazil, which accounts for 295 of a total of 458 cases of the disease ${ }^{17}$, and affects mainly rural workers that live in constant contact with vegetation and soil, such as the rubber tree tappers from the Amazon ${ }^{12,17}$.

In skin lesions, L. loboi is characterized by a round or oval shape, a thick well-refringent cell wall, a homogenous or granular cytoplasm, and a cell size ranging from 6 to $12 \mu \mathrm{m}$ in diameter. The fungus reproduces by single or multiple budding, presenting a chain-like arrangement in which individual cells are interconnected by tube-like structures ${ }^{12}$.

Electron microscopic analysis shows that L. loboi possesses various nuclei and that its cytoplasm contains mitochondria, endoplasmic reticulum, ribosomes, vesicles and lipid droplets ${ }^{9,22,23,29}$. Its cell wall is trilaminar and the outermost layer is lined with scales arranged like tiles on a roof ${ }^{2}$.

The viability of $L$. loboi from skin lesion biopsies of patients is donely using fluorescein diacetate and ethidium bromide dyes and has shown a rate ranging from 21 to $46 \%$, and that a large number of fungal cells present in the lesions do not contain any structure, resembling empty capsules, which correspond to inviable cells ${ }^{26}$ as suggested by SESSO \& BARUZZI ${ }^{22}$.

One peculiarity of $L$. loboi is the fact that the fungus has not been cultured in artificial media so far despite numerous attempts ${ }^{8,12,18}$. However, the development of an experimental model of Jorge Lobo's disease in BALB/c mice, which show histological alterations similar to the human disease with a large number of viable fungi ${ }^{14}$, has contributed to the study of this mycosis.

Studies investigating the immunological aspects of Jorge Lobo's disease are still scarce. In 2004, VILANI-MORENO et al. ${ }^{28}$ determined the cytokine profile in the culture supernatant of peripheral blood mononuclear cells from 15 patients with the mycosis and observed the predominance of a Th2 profile. In a previous study, evaluation of serum immunoglobulins revealed increased levels of $\operatorname{IgG}, \operatorname{IgA}$ and $\operatorname{IgM}$ in $52 \%, 29 \%$ and $5 \%$ of patients, respectively ${ }^{20}$, in agreement with the finding of a Th2 profile in these patients. Quantification of the serum C3 fraction of complement showed elevated levels of this protein in $71.4 \%$ of patients ${ }^{16}$.

The activation of the complement system (CS) by the classical, 


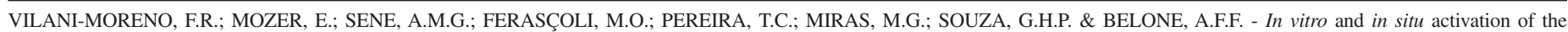
complement system by the fungus Lacazia loboi. Rev. Inst. Med. trop. S. Paulo, 49(2): 97-101, 2007.

alternative or lectin pathway produces chemotactic factors, anaphylatoxins and opsonins which are important in the defense against microorganisms. Since no study has been done so far evaluating the participation of the complement in Jorge Lobo's disease and its activity on the fungus Lacazia loboi, we carried out the present investigation.

\section{MATERIAL AND METHODS}

Fungal suspension: L. loboi was obtained from the footpads of BALB/c mice previously inoculated for maintenance of the $\operatorname{strain}^{14}$. The animals were sacrificed 10 months post-inoculation and the hind footpads were removed and macerated in sterile saline. The fungal suspension (pool) obtained was evaluated regarding the number of fungi and viability index and subsequently used for evaluation of complement activity.

Determination of fungal viability: Fungal viability was determined by vital staining with fluorescein diacetate-ethidium bromide (FD-EB) ${ }^{6}$ as described for L. loboi by VILANI-MORENO \& OPROMOLLA $^{26}$. Fungi showing a green fluorescent color were classified as viable and those becoming orange were classified as inviable. Percent viability was determined by counting 100 fungal cells.

Fungal concentration in the suspension: The concentration of fungi was determined by cell counting in a Neubauer chamber and the results are expressed as absolute number.

Blood serum: A pool of sera from patients with Jorge Lobo's disease and a pool of sera from healthy $\mathrm{AB}$ individuals (normal human serum - NHS), as human complement source, were used. The sera were divided into aliquots and stored at $-20{ }^{\circ} \mathrm{C}$.

Test for the evaluation of complement activity on $\mathbf{L}$. loboi: The technique of KRETTLI et al. ${ }^{11}$ was used. Briefly, 11 tubes containing $0.2 \mathrm{~mL}$ of the fungal suspension $\left(2 \times 10^{6}\right.$ cells $)$ were incubated at $37^{\circ} \mathrm{C}$ for $30 \mathrm{~min}$ with $0.2 \mathrm{~mL}$ inactivated patient serum (tubes 1 to 5) or sterile saline (tubes 6 to 11). Next, the tubes were centrifuged at 1500 rpm for five min and washed once with sterile saline. Fungi in tubes 1 and 6 were resuspended in $0.5 \mathrm{~mL}$ noninactivated NHS, tubes 2 and 7 in inactivated NHS, tubes 3 and 8 in noninactivated NHS diluted 1:2 in $10 \mathrm{mM}$ EGTA [ethylene glycol-bis( $\beta$-aminoethyl ether)-N,N,N',N'tetraacetic acid] containing $2 \mathrm{mM} \mathrm{MgCl}$ (Sigma-Aldrich Co., St. Louis, MO, USA), tubes 4 and 9 in $0.5 \mathrm{~mL}$ noninactivated NHS diluted 1:2 in EDTA [ethylenediaminetetraacetic acid] (Sigma-Aldrich), tubes 5 and 10 in noninactivated NHS diluted 1:2 in sterile saline, and tube 11 was resuspended in sterile saline only (control tube of the fungal suspension). The EGTA- $\mathrm{MgCl}_{2}$ and EDTA solutions were used to block the classical pathway of CS activation ${ }^{7}$ and the classical and alternative activation pathways ${ }^{24}$, respectively. The tubes were incubated at $37^{\circ} \mathrm{C}$ for two h. Next, the tubes were centrifuged at $1500 \mathrm{rpm}$ for five min and the fungal suspension was resuspended in $0.5 \mathrm{~mL}$ sterile saline. The viability of the fungi was evaluated using the FD-EB technique as described above. The remaining fungal suspension was analyzed by immunofluorescence using anti-C3 monoclonal antibody.

Fungal immunofluorescence: Fungal cells were cytocentrifuged at $1500 \mathrm{rpm}$ for five min and slides were air dried and fixed in acetone for five min. After washing in phosphate-buffer saline (PBS), $\mathrm{pH} 7.2$, and drying, the slides were placed in a humid chamber and conjugate (fluorescein isothiocyanate-conjugated human anti-C3c monoclonal antibody; Dako Co., Carpinteria, CA, USA) diluted 1:200 in Evans blue-Tween 20 was added to each orifice. The slides were incubated for $30 \mathrm{~min}$ at $37^{\circ} \mathrm{C}$, washed, dried and mounted in buffered glycerine. Next, 100 fluorescent and non-fluorescent fungal cells were counted under a fluorescence microscope.

Collection of skin lesions: A fragment of the skin lesions from 11 patients with Jorge Lobo's disease from the State of Acre was collected by biopsy or by complete surgical removal of the lesion, as indicated for each case. The fragment was immersed in OCT (Tissue-Tek, Sakura Finetechnical Co., Tokyo, Japan), frozen in liquid nitrogen and stored in a freezer at $-80^{\circ} \mathrm{C}$ until the time of use. The frozen material was cut with a cryostat at $-26{ }^{\circ} \mathrm{C}$ into $4-\mu \mathrm{m}$ thick sections, and the sections were mounted on silanized slides (Sigma-Aldrich) for subsequent detection of immunoglobulins and complement by immunofluorescence.

Immunofluorescence study of skin lesions: The slides containing the sections obtained from frozen tissue were kept overnight at $4{ }^{\circ} \mathrm{C}$ and were then fixed in ice-cold acetone for $10 \mathrm{~min}$. Next, the slides were washed three times in PBS, air dried, and placed in a humid chamber. The sections were incubated at $37{ }^{\circ} \mathrm{C}$ for $30 \mathrm{~min}$ with the following fluorescein conjugates: total anti- $\operatorname{Ig}$, anti- $\operatorname{IgG}$, anti-IgA, anti-IgM, and anti-C3c (Dako) at dilutions of 1:800, 1:800, 1:200, 1:200, and 1:200, respectively. The slides were then washed, dried and mounted in buffered glycerin containing Evans blue. Sections in which the conjugate was omitted were used as negative control. The slides were examined under a fluorescence microscope and evaluated regarding the presence of immunoglobulins and complement deposited in the fungal wall inside granulomas. The slides were evaluated by three observers and the results are expressed on a semiquantitative scale, where $0=$ absent, $1+=$ minimal, $2+=$ discrete, $3+=$ moderate , and $4+=$ intense.

\section{RESULTS}

The results regarding the determination of viability of $L$. loboi and C3 fixation with the different treatments are shown in Table 1. The initial viability of the fungus was $48 \%$ and this index did not change significantly after complement activation for two h. Complement fixation was $84 \%$ and $85 \%$ with NHS in the presence and absence of patient serum, respectively. When NHS was diluted 1:2 in sterile saline, these percentages fell to $75 \%$ and $78 \%$. Dilution of NHS in EGTA$\mathrm{MgCl}_{2}$ led to complement activation by the alternative pathway, with $98 \%$ fixation (Fig. 1). No C3 fixation was observed when NHS was diluted in EDTA and no fluorescence was observed for tube 11 since the fungi were only incubated with sterile saline. It should be noted that the assay for the evaluation of complement activity on L. loboi was carried out using three different fungal suspensions and similar results were obtained for the three assessments.

The presence or absence of immunoglobulins and complement in the granulomas of skin lesions from patients with Jorge Lobo's disease is shown in Table 2. Deposits involving fungi included $\operatorname{IgG}, \operatorname{IgA}, \operatorname{IgM}$ and $\mathrm{C} 3$ in $91 \%, 27 \%, 18 \%$ and $100 \%$ of the patients, respectively. In most cases these deposits were characterized by a homogenous linear staining of the fungal cell wall (Fig. 2). No staining was observed in the sections used as control in which the conjugate was omitted. 


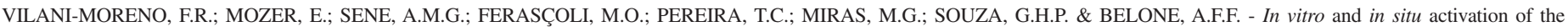
complement system by the fungus Lacazia loboi. Rev. Inst. Med. trop. S. Paulo, 49(2): 97-101, 2007.

Table 1

Evaluation of complement activity on the fungus Lacazia loboi

\begin{tabular}{lccccc}
\hline L. loboi & $\begin{array}{c}\text { Patient } \\
\text { serum }\end{array}$ & NHS $^{\mathrm{a}}$ & $\begin{array}{c}\text { Chelating } \\
\text { agent }\end{array}$ & $\begin{array}{c}\text { Viability } \\
(\%)\end{array}$ & $\begin{array}{c}\text { C3 fixation } \\
(\%)\end{array}$ \\
\hline+ & + & NI $^{\mathrm{b}}$ & - & 45 & 84 \\
+ & + & $\mathrm{I}^{\mathrm{c}}$ & - & 44 & - \\
+ & + & $\mathrm{NI}(1: 2)$ & EGTA-MgCl$_{2}$ & 46 & 96 \\
+ & + & $\mathrm{NI}(1: 2)$ & EDTA & 45 & - \\
+ & + & NI $(1: 2)$ & - & 44 & 75 \\
+ & - & NI & - & 44 & 85 \\
+ & - & I & - & 45 & - \\
+ & - & NI (1:2) & EGTA-MgCl & 44 & 98 \\
+ & - & NI (1:2) & EDTA & 46 & - \\
+ & - & NI (1:2) & - & 44 & 78 \\
+ & - & - & - & 47 & - \\
\hline
\end{tabular}

a. normal human serum, b. noninactivated, c. inactivated.

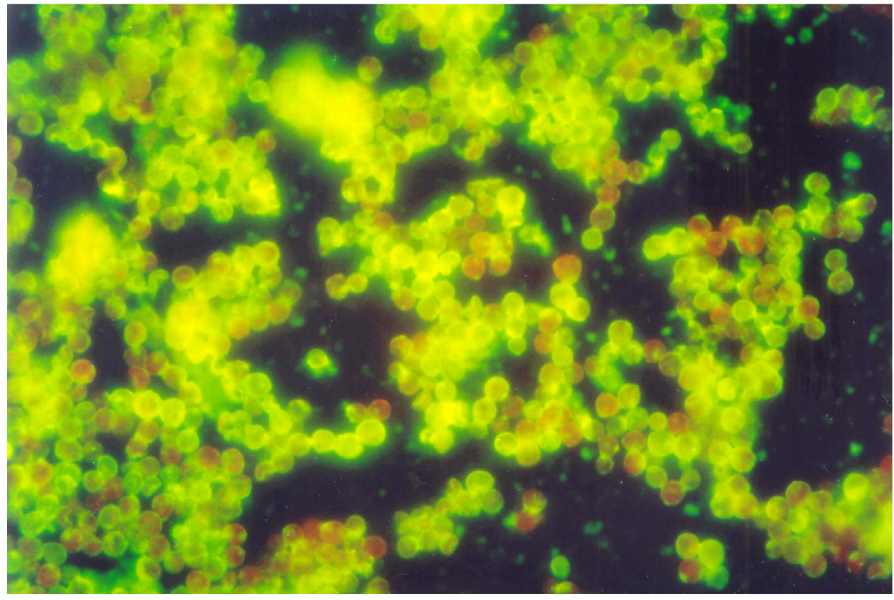

Fig. 1 - C3 deposit in the cell wall of Lacazia loboi. Fungal suspension treated with normal human serum. Immunofluorescence (magnification: 400x).

Table 2

Presence of immunoglobulins and complement in granulomas of skin lesions from patients with Jorge Lobo's disease

\begin{tabular}{lccccc}
\hline Patient & Total Ig & IgG & IgA & IgM & C3 \\
\hline 1 & $2+$ & $2+$ & 0 & 0 & $2+$ \\
2 & $1+$ & $1+$ & $1+$ & 0 & $4+$ \\
3 & 0 & 0 & 0 & 0 & $4+$ \\
4 & $3+$ & $2+$ & 0 & $1+$ & $1+$ \\
5 & $3+$ & $3+$ & $2+$ & $1+$ & $3+$ \\
6 & $1+$ & $1+$ & 0 & 0 & $1+$ \\
7 & $2+$ & $2+$ & 0 & 0 & $3+$ \\
8 & $1+$ & $1+$ & 0 & 0 & $1+$ \\
9 & $1+$ & $1+$ & 0 & 0 & $1+$ \\
10 & $3+$ & $3+$ & $1+$ & 0 & $2+$ \\
11 & $3+$ & $3+$ & 0 & 0 & $2+$ \\
Median & $2+$ & $2+$ & 0 & 0 & $2+$ \\
\hline
\end{tabular}

$0=$ absent $1+=$ minimal $; 2+=$ discrete $3+=$ moderate 4+ = intense.
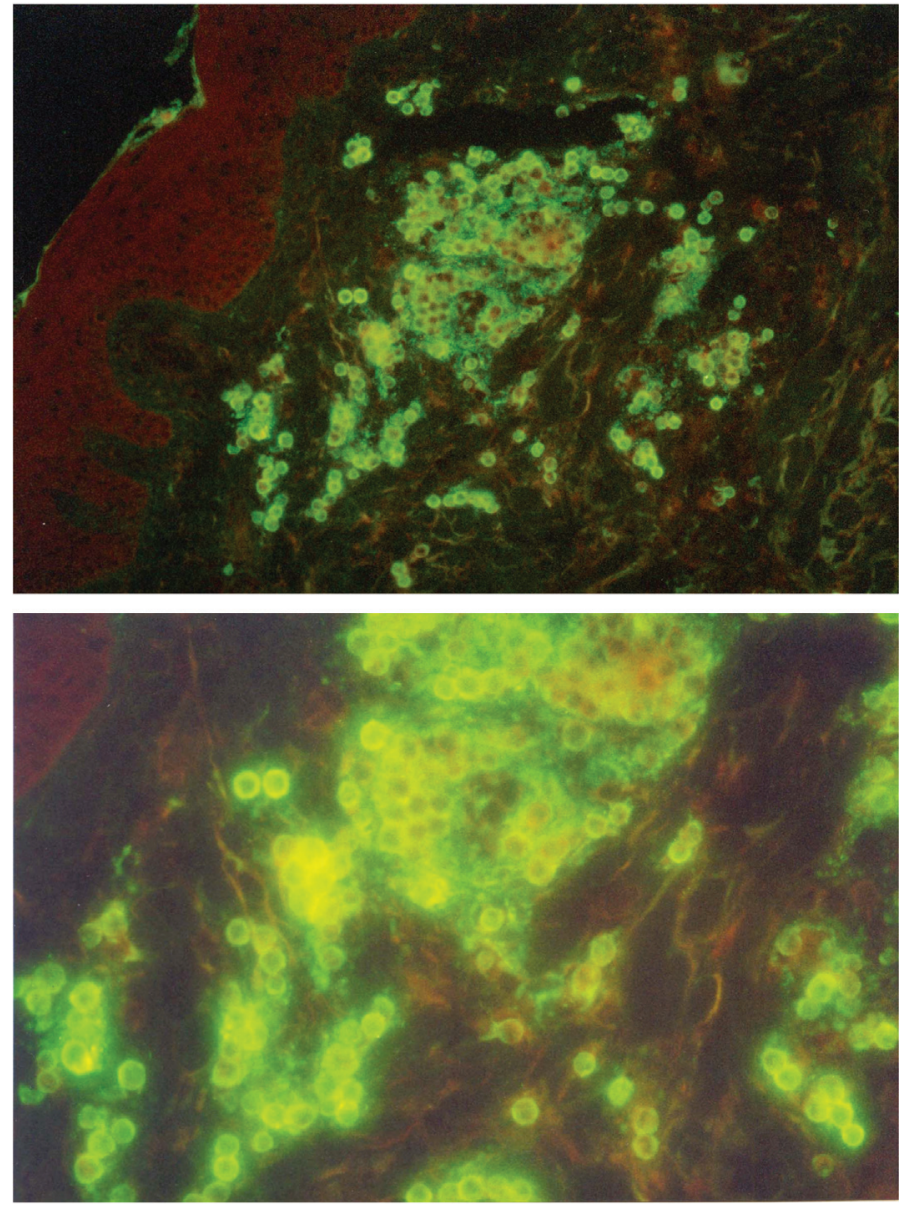

Fig. 2 - C3 deposit in the cell wall of Lacazia loboi in a skin lesion from a patient with Jorge Lobo's disease. Immunofluorescence (magnification: top, 200x and bottom, 400x).

\section{DISCUSSION}

The CS is one of the main effector mechanisms of humoral as well as innate immunity. This system can be activated by the classical, alternative or lectin pathway. CS activation by the classical pathway is commonly initiated by the formation of soluble antigen-antibody complexes or by the binding of an antibody to an antigen on the appropriate target such as, for example, a fungal cell. The alternative pathway, on the other hand, does not depend on the participation of antibodies, therefore being a component of the innate immune system. This activation pathway involves four serum proteins $(\mathrm{C} 3$, factor $\mathrm{B}$, factor $\mathrm{D}$ and properdin) and is initiated by different components on the cell surface that are foreign to the host. Both bacteria and fungi possess constituents in their cell wall that can activate the alternative pathway $^{1,10}$. Similar to the alternative pathway, the lectin pathway does not depend on antibodies for its activation. Lectins are proteins that bind to carbohydrates (mannose) present on the surface of microorganisms. Binding of mannose-binding lectin (MBL) to mannose residues of the microorganism, together with serine protease, initiates the complement cascade through the $\mathrm{C} 4$ component ${ }^{1,10}$.

In the present study, L. loboi was found to be able to activate the 


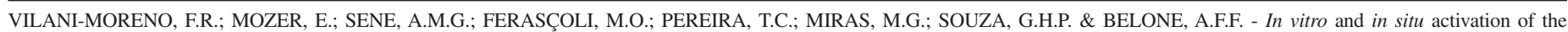
complement system by the fungus Lacazia loboi. Rev. Inst. Med. trop. S. Paulo, 49(2): 97-101, 2007.

CS in vitro by the alternative pathway. Several studies have evaluated the activation of the CS by fungal cells. RAY \& WUEPPER ${ }^{19}$ reported that Candida albicans activates the CS in vitro by the alternative pathway, producing chemotactic factors, anaphylatoxins and opsonins that might be important in the defense against this agent. Similarly, SWAN et al. ${ }^{24}$ described alternative activation of the CS by the fungus Trichophyton rubrum and suggested that the complement plays a role in the defense against these microorganisms. In paracoccidioidomycosis, CALICH et al. ${ }^{5}$ demonstrated that $P$. brasiliensis activates the CS by the alternative pathway, resulting in opsonization of the fungus and facilitation of macrophage-mediated phagocytosis. In another study, the authors ${ }^{4}$ evaluated lysis of $P$. brasiliensis by the CS and reported a mortality rate of 30 to $50 \%$. More recently, MUNK \& SILVA $^{15}$ showed that the fungus $P$. brasiliensis activates the CS by the alternative pathway but this event does not reduce its viability.

In the present study, CS activation did not reduce the viability of L. loboi, probably because of the short period of incubation $(2 \mathrm{~h})$. Incubation of the fungus in noninactivated NHS (tube 6) and only in sterile saline (tube 11, control) for $24 \mathrm{~h}$ at $37^{\circ} \mathrm{C}$ did not yield satisfactory results, with the loss of fungal viability. In a previous study, we have demonstrated that a temperature of $37^{\circ} \mathrm{C}$ is inefficient in maintenance of L. loboi viability, since viable fungi were no longer observed by the third day of incubation ${ }^{26}$. In addition, since $L$. loboi has not been cultured in artificial media its viability cannot be determined by colony count technique, a method commonly employed for fungi ${ }^{21}$.

As observed in this study, the presence of immunoglobulins and C3 in Jorge Lobo's granulomas suggests that antibodies bound to the fungi may function as opsonin and facilitate macrophage-mediated phagocytosis of the microorganism, in addition to CS activation. This activation by the classical pathway would potentiate opsonization, favoring endocytosis and destruction of the microorganism by microbicidal mechanisms of the phagocytic cells. This hypothesis is supported by the finding of fungi with morphological features of inviability in the inflammatory infiltrate ${ }^{27}$. Furthermore, the observation in the present study of predominantly IgG deposits might be due to the fact that Jorge Lobo's disease is a chronic infectious disease and, consequently, the antigen stimulus is constant.

C3 was detected in all lesions analyzed, a finding that may also be the result of the fungus ability to activate the CS by the alternative pathway. However, since we observed IgG deposits in the fungal wall, it is possible that $\mathrm{C} 3$ results from classical pathway activation through an antigen-antibody reaction. The finding of plasma cells in the inflammatory infiltrate which, although not abundant, were always detected in the lesions analyzed, agrees with this view ${ }^{27}$.

The present results agree with those obtained for peripheral blood of patients with Jorge Lobo's disease. In this respect, studies have demonstrated the participation of the humoral immune response in Jorge Lobo's disease, with patients showing high serum levels of immunoglobulins and of the $\mathrm{C} 3$ component of the complement ${ }^{16,20}$. In addition, the present findings support those reported by our group in a previous study demonstrating that patients with the mycosis present an altered cytokine pattern represented by the predominance of a Th2 profile $^{28}$.
The detection of antibodies and complement in tissue lesions was previously described in paracoccidioidomycosis by BIAGIONI et al. ${ }^{3}$. They demonstrated the presence of IgG and C3 in the fungal wall in the center of the paracoccidioidal granuloma and suggested that specific antibodies bound to the fungus blocking antigen diffusion from the granulomas and activate the CS, thus facilitating the destruction of parasites by phagocytosis or lysis.

Taken together, the present results show that the fungus $L$. loboi is able to activate the CS by the alternative pathway. The presence of $\mathrm{C} 3$ and immunoglobulins in skin lesions from patients with Jorge Lobo's disease suggests the participation of these proteins in the defense mechanisms of the host against the fungus.

\section{RESUMO}

\section{Ativação in vitro e in situ do sistema complemento pelo fungo Lacazia loboi}

Considerando que não existe nenhum estudo avaliando a participação do sistema complemento (SC) na doença de Jorge Lobo e sua atividade sobre o fungo Lacazia loboi, realizamos o presente trabalho. Os fungos foram obtidos dos coxins plantares de camundongos BALB/c com índice de viabilidade de $48 \%$ e, em seguida, foram incubados com pool de soro inativado de pacientes ou com solução salina estéril (SSE) por $30 \mathrm{~min}$, a $37{ }^{\circ} \mathrm{C}$. Os tubos foram incubados, por $2 \mathrm{~h}$, com pool de soro $\mathrm{AB}^{+}$sem inativar, inativado, diluído em EGTA- $\mathrm{MgCl}_{2}$ e EDTA. A viabilidade do L. loboi foi avaliada e a suspensão fúngica foi citocentrifugada. As lâminas foram submetidas à técnica de imunofluorescência empregando o anticorpo anti-C3 humano. Os resultados revelaram que $98 \%$ dos fungos ativaram o SC pela via alternativa e que não houve diferença significante na viabilidade do L. loboi após ativação do SC. Em paralelo, cortes histológicos congelados de 11 pacientes foram avaliados quanto à presença de $\mathrm{C} 3 \mathrm{e}$ $\mathrm{IgG}$, pela técnica de imunofluorescência. Foram encontrados depósitos de C3 e de IgG na parede dos fungos em $100 \%$ e $91 \%$ das lesões avaliadas, respectivamente. Os resultados sugerem que o $\mathrm{SC}$ e as imunoglobulinas poderiam contribuir nos mecanismos de defesa do hospedeiro contra o L. loboi.

\section{REFERENCES}

1. ABBAS, A.K. \& LICHTMAN, A.H. - Imunologia celular e molecular. 5. ed. Rio de Janeiro, Elsevier, 2005.

2. ABREU, W.M. \& MIRANDA, J.L. - Microscopia eletrônica scanning: agente da micose de Jorge Lobo. An. bras. Derm., 47: 115-124, 1972.

3. BIAGIONI, L.M.V.; ORSI, S.; CHAMMA, L.G.; SADATSUNE, T. \& FRANCO, M. Imunoglobulinas e C3 no granuloma paracoccidióidico. Rev. Inst. Med. trop. S. Paulo, 29: 97-103, 1987.

4. CALICH, V.L.G. \& TEIXEIRA, R.C.V. - Antibody and complement-dependent cytotoxicity against Paracoccidioides brasiliensis. In: ENCONTRO SOBRE PARACOCCIDIOIDOMICOSE, 2., Botucatu, 1983. Anais. p. 8.

5. CALICH, V.L.G.; KIPNIS, T.L.; MARIANO, M.; FAVA-NETTO, C. \& SILVA, W.D. The activation of the complement system by $P$. brasiliensis in vitro: its opsonic effect and possible significance for an in vivo model of infection. Clin. Immunol. Immunopath., 12: 20-30, 1979. 


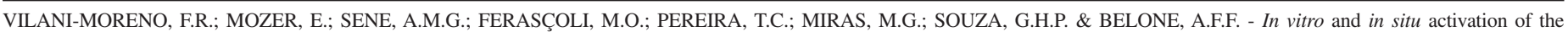
complement system by the fungus Lacazia loboi. Rev. Inst. Med. trop. S. Paulo, 49(2): 97-101, 2007.

6. CALICH, V.L.G.; PURCHIO, A. \& PAULA, C.R. - A new fluorescent viability test for fungi cells. Mycopathologia (Den Haag), 66: 175-177, 1979.

7. FINE, D.P.; MARNEY Jr., S.R.; COLLEY, D.G.; SARGENT, J.S. \& DESPREZ, R.M. C3 shunt activation in human serum chelated with EGTA. J. Immunol., 109: $807-$ 809, 1972.

8. FONSECA, O.J.M. \& LACAZ, C.S. - Estudo de culturas isoladas de blastomicose queloidiforme (doença de Jorge Lobo). Denominação ao seu agente etiológico. Rev. Inst. Med. trop. S. Paulo, 13: 225-252, 1971.

9. FURTADO, J.S.; BRITO, T. \& FREYMULLER, E. - Structure and reproduction of Paracoccidioides loboi. Mycologia, 59: 286-294, 1967.

10. GOLDSBY, R.A.; KINDT, T.J. \& OSBORNE, B.A. - Kuby Imunologia. 4. ed. Rio de Janeiro, Revinter, 2002.

11. KRETTLI, A.U.; WEISZ-CARRINGTON, P. \& NUSSENZWEIG, R.S. - Membranebound antibodies to bloodstream Trypanosoma cruzi in mice: strain differences in susceptibility to complement mediated lysis. Clin. exp. Immunol., 37: 416-423, 1979.

12. LACAZ, C.S.; BARUZZI, R.G. \& ROSA, M.C.B. - Doença de Jorge Lobo. São Paulo, USP-IPSIS, 1986.

13. LOBO, J. - Um caso de blastomicose produzido por uma espécie nova encontrada em Recife. Rev. méd. Pernambuco., 1: 763-775, 1931.

14. MADEIRA, S.; OPROMOLLA, D.V.A. \& BELONE, A.F.F. - Inoculation of BALB/c mice with Lacazia loboi. Rev. Inst. Med. trop. S. Paulo, 42: 239-243, 2000.

15. MUNK, M.E. \& SILVA, W.D. - Activation of human complement system Paracoccidioides brasiliensis and its deposition on the yeast form cell surface. J. med. vet. Mycol., 30: 481-484, 1992.

16. NOGUEIRA, M.E.S.; VILANI-MORENO, F.R.; MARCOS, E.V.C. \& SILVA, E.A. Avaliação imunológica de pacientes portadores da doença de Jorge Lobo. In: CONGRESSO DA SOCIEDADE BRASILEIRA DE MEDICINA TROPICAL, 36., São Luís, 2000. Anais. p. 274-275.

17. OPROMOLLA, D.V.A.; TABORDA, P.R.O.; TABORDA, V.B.A.; VIANA, S. \& FURTADO, J.F. - Lobomicose: relato de 40 casos novos. An. bras. Derm., 74: 135 $141,1999$.

18. OPROMOLLA, D.V.A.; VILANI-MORENO, F.R.; ANDRADE, M.I. \& WECWERTH, A.C.V.B. - Tentativas de cultivo do Lacazia loboi. In: CONGRESSO BRASILEIRO DE DERMATOLOGIA, 56., Goiânia, 2001. Anais. p. 130.
19. RAY, T.L. \& WUEPPER, K.D. - Activation of the alternative (properdin) pathway of complement by Candida albicans and related species. J. invest. Derm., 67: 700703, 1976.

20. RODRIGUES, L.A.P.; DALPINO, D.; DAINEZI, E.M.; MIRAS, M.R.G. \& VILANIMORENO, F.R. - Quantificação dos níveis séricos de imunoglobulinas e perfil eletroforético das proteínas em pacientes com doença de Jorge Lobo. In: CONGRESSO BRASILEIRO DE PATOLOGIA CLÍNICA, 37., Rio de Janeiro, 2003. Anais. p. 157

21. SANO, A.; KURITA, N.; COELHO, K.I.R. et al. - A comparative study of four different staining methods for estimation of live yeast form cells of Paracoccidioides brasiliensis. Mycopathologia (Den Haag), 124: 157-161, 1993.

22. SESSO, A. \& BARUZZI, R.G. - Interaction between macrophage and parasite cells in lobomycosis. The thickened cell wall of Paracoccidioides loboi exhibits apertures to the extracellular milieu. J. submicrosc. Cytol. Path., 20: 537-548, 1988.

23. SESSO, A.; AZEVEDO, R.A. \& BARUZZI, R.G. - Lanthanum nitrate labelling of the outer cell wall surface of phagocytized Paracoccidioides loboi in human lobomycosis. J. submicrosc. Cytol. Path., 20: 769-772, 1988.

24. SWAN, J.W.; DAHL, M.V.; COPPO, P.A. \& HAMMERSCHMIDT, D.E. - Complement activation by Trichophyton rubrum. J. invest. Derm., 80: 156-158, 1983.

25. TABORDA, P.R.; TABORDA, V.A. \& McGINNIS, M.R. - Lacazia loboi gen. nov., comb. nov., the etiologic agent of lobomycosis. J. clin. Microbiol., 37: 2031-2033, 1999.

26. VILANI-MORENO, F.R. \& OPROMOLLA, D.V.A. - Determinação da viabilidade do Paracoccidioides loboi em biópsias de pacientes portadores de doença de Jorge Lobo. An. bras. Derm., 72: 433-437, 1997.

27. VILANI-MORENO, F.R.; BELONE, A.F.F.; SOARES, C.T. \& OPROMOLLA, D.V.A. Immunohistochemical characterization of the cellular infiltrate in Jorge Lobo's disease. Rev. iberoamer. Micol., 22: 44-49, 2005.

28. VILANI-MORENO, F.R.; LAURIS, J.R.P. \& OPROMOLLA, D.V.A. - Cytokine quantification in the supernatant of mononuclear cell cultures and in blood serum from patients with Jorge Lobo's disease. Mycopathologia, 158: 17-24, 2004.

29. WOODARD, J.C. - Electron microscopic study of lobomycosis (Loboa loboi). Lab. Invest., 27: 606-612, 1972.

Received: 26 April 2006

Accepted: 4 September 2006 